\section{Overhead and Drip-tube Irrigation Affect Twospotted Spider Mites and their Biological Control by a Predatory Mite on Impatiens}

\author{
George P. Opit ${ }^{1}$ \\ Department of Entomology, Kansas State University, Manhattan, KS 66506-4004
}

Greg K. Fitch ${ }^{2}$

Department of Biology, Avila University, Kansas City, MO 64145

David C. Margolies ${ }^{3}$ and James R. Nechols ${ }^{3}$
Department of Entomology, Kansas State University, Manhattan, KS 66506-4004

Kimberly A. Williams ${ }^{4}$

Department of Horticulture, Forestry, and Recreation Resources, Kansas State University, Manhattan, KS 66506-5506

Additional index words. bedding plants, Chapin tube irrigation, hand watering, Impatiens wallerana, integrated crop management, integrated pest management, microtube irrigation, Phytoseiulus persimilis, spaghetti tube irrigation, Tetranychus urticae

\begin{abstract}
The effects of overhead and drip tube irrigation on twospotted spider mite (TSMs) (Tetranychus urticae Koch) and predatory mite (PMs) (Phytoseiulus persimilis Athias-Henriot) populations, as well as the biological control of TSMs by PMs, were investigated on Impatiens wallerana Hook. f. 'Impulse Orange'. To determine the effects of the two irrigation methods on TSM populations, plants were inoculated with female TSMs 6 weeks after seeding. Plants were then irrigated twice every three days, and TSM counts were taken 3 weeks later. To assess the effects of irrigation method on PMs, plants were inoculated with TSMs 6 weeks after seeding, PMs were released 10 days later, plants were irrigated about once per day, and the number of predatory mites on plants was counted 3 weeks after release. To assess the effects of irrigation method on the biological control of TSMs by PMs, plants were inoculated with TSMs and PMs were released as before, but then plants were irrigated either three times every 2 days or three times every 4 days using either drip or overhead irrigation. The number of TSMs on plants and the number of leaves showing TSM feeding injury were measured 3 weeks after predator release. Overhead watering significantly reduced TSM and PM populations as much as 68- and 1538-fold, respectively, compared to drip irrigation with microtubes. Perhaps more important, overhead watering with or without predators significantly reduced the number of leaves sustaining TSM feeding injury as much as 4-fold compared to drip irrigation. These results confirm the common observation that TSM infestations and injury may be reduced by irrigation systems that wet plant foliage. However, predators still reduced TSMs even though overhead irrigation had a suppressive effect on predatory mites. Predators are particularly useful for reducing TSM injury when plants are watered infrequently. Overhead watering could be used in tandem with biological control as a component of an integrated crop management program for TSMs in ornamental greenhouses by rapidly lowering TSM population levels in hot spots before PMs are released.
\end{abstract}

Overhead irrigation via hand watering is the only practical irrigation system in some production situations, such as in ornamental greenhouse operations that produce small

blocks of numerous plant species and container sizes (Dole and Wilkins, 2005). However, plant production has become a highly competitive business, demanding high efficiency in all as-

Received for publication 19 Sept. 2005. Accepted for publication 11 Dec. 2005. This research was supported by USDA Pest Management Alternatives Program (PMAP) Grant 2002-34381-12146. This manuscript has been assigned Contribution no. 06-012-J from the Kansas Agricultural Experiment Station (KAES). We thank the following individuals, all from Kansas State University, for their assistance: Xiaoli Wu, Fahad Alatawi, and Junrui Chi for helping with mite counts, and Catherine Whalen for providing support in irrigating plants. We gratefully acknowledge Syngenta Seeds, Inc., Downers Grove, Ill., for providing the seeds used in these experiments and Raymond Cloyd for his initial suggestion of this research topic and review of the manuscript in collaboration on the PMAP project. The use of trade names in this publication does not imply endorsement by the KAES of products named nor criticism of similar ones not mentioned.

${ }^{1}$ Postdoctoral research associate.

${ }^{2}$ Associate professor of biology.

${ }^{3}$ Professor of entomology.

${ }^{4}$ Associate professor of horticulture; corresponding author; e-mail kwilliam@ksu.edu. pects of crop production management in order to maintain profitability, and hand watering is often not cost effective due to high labor costs (Nelson, 2003). Furthermore, hand watering wastes water and may increase the incidence of plant disease because it results in frequently wet foliage, splashing water, and a humid environment in the foliage canopy (Jarvis, 1992). Given this scenario, most growers are investing in automatic irrigation systems to increase the efficiency of irrigation and minimize labor costs (Nelson, 2003). Examples of irrigation systems replacing hand watering include subirrigation systems like ebb and flow, trough irrigation, and capillary mats; surface delivery systems like drip or microtube irrigation; and overhead irrigation systems like stationary overhead sprinklers and boom sprayers.

A change in irrigation system, especially a shift to a delivery system that does not wet foliage, may directly or indirectly impact other aspects of production in greenhouses, including arthropod pest management. The twospotted spider mite (TSM), Tetranychus urticae Koch (Acari: Tetranychidae), is a small $(0.5 \mathrm{~mm}$ in length) generalist herbivore that is a severe arthropod pest of many economically important ornamental crops grown in greenhouses (Smitley, 1993; van de Vrie et al., 1972). Overhead irrigation systems that wet plant foliage may help reduce arthropod pest populations in general (Castle et al., 1996; Gencsoylu and Yilmaz, 2003; McHugh and Foster, 1995; Nakahara et al., 1986; Parihar and Name, 1999) and spider mite populations in particular (Hudson and Beirne, 1970; Ranga et al, 1990). This pest is particularly vulnerable to being washed off foliage, which may cause physical damage, or to being killed by drowning (Holtzer et al. 1988). High humidity production environments have also been related to reduced TSM populations (Lindquist et al., 1987). Therefore, replacing overhead watering systems with irrigation systems that do not wet foliage might lead to increased problems with plant-feeding insects and mites. In fact, washing plant foliage is recommended in extension literature as a means of controlling spider mites on plants as varied as apple trees (Smith, 2001), home ornamentals (Cranshaw and Sclar, 2004), onions (Hall et al., 2000), and vegetable crops (Bauernfeind, 2004). However, several studies question the impact of overhead irrigation on spider mites and suggest that mites may actually be more of a problem with overhead irrigation (Latimer and Oetting, 1999; White and Liburd, 2005).

The predatory mite (PM) Phytoseiulus persimilis Athias-Henriot (Acari: Phytoseidae) is commonly used as an effective biological control agent for TSMs on many crops grown in greenhouses. We have studied and advocated the use of this predator for spider mite control on bedding plants in commercial greenhouses (Holt, 2005; Opit et al., 2004, 2005). However, because this predator is approximately the same size as its prey, and lives on the leaf surface with its prey, it may also be substantially affected by overhead irrigation. This raises questions about the need for and effectiveness of biological control of spider mites by PMs when overhead irrigation is used. Few studies have examined 
the effects of overhead irrigation on Tetranychus species in controlled environments (e.g., Latimer and Oetting, 1999). Furthermore, no research has documented the effects of watering on PM population growth on ornamental crops, or on the effects of watering methods on biological control of TSMs using PMs. Therefore, we conducted a series of experiments to investigate the effects of overhead and drip tube irrigation on both TSM and PM populations, and on biological control of TSMs using PMs, on Impatiens wallerana 'Impulse Orange' Hook. f. (Ericales: Balsaminaceae). This species and cultivar was selected because of its susceptibility to feeding damage from TSMs.

\section{Materials and Methods}

Growing conditions. A series of experiments described below were conducted at three times: first from September to November 2003 (Fall 2003), then from January to March 2004 (Winter 2004), and finally from August to October 2004 (Summer 2004). All experiments were set in $7.6 \times 7.6-\mathrm{m}$ glass greenhouses at Kansas State University, Manhattan Impatiens wallerana ' Impulse Orange' (Syngenta Seeds, Inc., Downer's Grove, Ill.) was used in all experiments; seeds were propagated in 200-cell plug trays that were placed under mist. Seedlings were transplanted, two per $8.9 \times 8.9$-cm pot, after either 4 weeks (Fall 2003 and Winter 2004 experiments) or 2.5 weeks (Summer 2005 experiment). Root medium was Pro-Mix BX (Premier Horticulture, Dorval, Que.), which consisted of about $70 \%$ low-humified sphagnum peatmoss to $30 \%$ horticultural grade perlite and vermiculite. Pot spacing was $36 \times 50 \mathrm{~cm}$; at this spacing, plants did not contact each other throughout the length of the experiments. To further minimize possible movement of TSMs or PMs among pots, each pot was placed on an inverted plastic container that sat in a pool of water or moat held in a $25.3-\mathrm{cm}$ plastic saucer (Opit et al., 2004).

Until plants were inoculated with spider mites, all plants were overhead watered by hand at a frequency based on water loss from the pots measured by weight loss. Eight (Fall 2003 and Winter 2004) or twelve (Summer 2004) pots of impatiens were weighed at least once per day and all pots were irrigated when the weight of at least half of the weighed pots dropped by $30 \%$ from their weight at container capacity. This was equivalent to watering plants twice every three days. Irrigation was performed using a solution of $200 \mathrm{mg} \mathrm{N} / \mathrm{L}$ from $20 \mathrm{~N}-0.43 \mathrm{P}-16.6 \mathrm{~K}$ fertilizer (Peter's 20-10-20 Peat-Lite Special, Scotts Co., Marysville, Ohio).

Temperature and relative humidity data were collected every 30 min using a HOBO environmental monitor(Onset Computer Corp., Bourne, Mass.). In Fall 2003, temperatures in the greenhouse were $26 \pm 8.6^{\circ} \mathrm{C}($ mean $\pm \mathrm{SD})$, but extremes as low as $16^{\circ} \mathrm{C}$ and as high as 44 ${ }^{\circ} \mathrm{C}$ occurred for short periods. Relative humidity was $39 \% \pm 14.9 \%$ (range $21 \%$ to $99 \%$ ). In Winter 2004 , temperature was $23 \pm 9.1^{\circ} \mathrm{C}$ (range 13 to $52{ }^{\circ} \mathrm{C}$ ), with relative humidity of $34 \% \pm 11.8 \%$ (range $23 \%$ to $89 \%$ ). Supplemental light from High Intensity Discharge(HID) lamps (Sunlight Supply, Inc., Vancouver, Wash.) above each bench suspended at a height of $50 \mathrm{~cm}$ provided 14L-10D photophase. In Summer 2004, temperature was $24 \pm 5.1^{\circ} \mathrm{C}$ (range 16 to $40^{\circ} \mathrm{C}$ ), with relative humidity of $45 \% \pm 16 \%$ (range $23 \%$ to $85 \%$ ). Light from HID lamps suspended above each bench at a height of $93 \mathrm{~cm}$ supplemented natural light for $12 \mathrm{~h}$ each day.

Mites. Twospotted spider mites were obtained from a laboratory colony maintained on lima beans (Phaseolus lunatus L.) at Kansas State University. Voucher specimens of TSMs have been deposited in the Kansas State University Museum of Entomological and Prairie Arthropod Researchunder Lot 135. Inoculation was accomplished by transferring the required number of TSMs from the colony onto $1.5-\mathrm{cm}$ diameter bean-leaf discs; TSM-infested discs were then placed on the impatiens plants. PMs were purchased from a commercial insectary (Koppert Biological Systems, Romulus, Mich.) before each experiment. Voucher specimens of PMs have been deposited in the Kansas State University Museum of Entomological and Prairie Arthropod Research under Lot 154. Predators were transferred onto leaf discs and released onto plants as above.

Irrigation. Watering frequency was determined based on $30 \%$ drop in pot weight from container capacity as described above. The number of times each treatment was watered was recorded, and at the end of the experiments, this data was translated into a descriptive watering frequency, such as twice every $3 \mathrm{~d}$. Drip tube irrigation used Chapin tubes (Chapin Watermatics, Inc., Watertown, N.Y.) with one microtube $(2 \mathrm{~mm}$ inside diameter and $3.3 \mathrm{~mm}$ outside diameter) placed in each pot, which delivered a measured amount of irrigation solution; foliage was not wetted. Overhead irrigation was accomplished by hand-watering over the top of the foliage canopy. This was done with a water breaker (Dramm 400 PL; Dramm Corp., Manitowoc, Wis.) and wand (0.4 $\mathrm{m}$ Dramm Handi-Reach hose extension handle) attached to a 1.9-cm-diameter hose; foliage was wetted at each application. Very close to the same volume of fertilizer solution was applied to plants in this treatment as to those watered by drip irrigation. This was accomplished by measuring the volume of solution needed to bring pots receiving irrigation from drip tubes to container capacity with a leaching fraction of $15 \%$, measuring the length of time required to deliver that same volume of solution with overhead irrigation equipment at a rate of 250 $\mathrm{cm}^{3} \cdot \mathrm{s}^{-1}$, and timing the application of solution from overhead irrigation to each pot to obtain this same volume. Care was taken to minimize water running off of foliage and out of the pot.

Effect of irrigation method on TSM populations. Two repetitions of this experiment were conducted: the first in Fall 2003 and the second in Winter 2004. Each replication was run as a randomized complete block design with two irrigation treatments and 12 blocks (replications). Six weeks after seeding, plants in each pot were inoculated with eight adult female TSMs in Fall 2003, or ten adult female TSMs in Winter 2004. Pots were then randomly assigned to either the hand watering or drip tube irrigation treatment. Irrigation treatments were not started until one day after inoculation, allowing the TSMs to become established on the impatiens plants. Three weeks after inoculation with TSMs, or 9 weeks after seeding, impatiens were destructively sampled and the number of TSMs per leaf was counted. PROC GLM (SAS, 2000) was used to run ANOVA to test the effects of irrigation on TSM populations. Treatment means were compared using Fisher's least significant difference (LSD) mean separation procedure.

Effect of irrigation method on PM populations. Two repetitions of this experiment were conducted at the same times and in the same greenhouses as the above experiments. However, impatiens used to study PMs were placed on a different $0.9 \times 4.6 \mathrm{~m}$ greenhouse bench than plants used to study TSMs. Each replication was run as a randomized complete block design with 2 irrigation treatments and 7 blocks (replications) in Fall 2003, or 12 blocks in Winter 2004. Six weeks after seeding, plants in each pot were inoculated with eight adult female TSMs in Fall 2003, or twenty adult female TSMs in Winter 2004. Following inoculation all pots were irrigated using drip tubes to allow TSM populations to establish and increase unimpeded for 2 weeks. After 2 weeks, three adult female PMs were released on impatiens in each pot. Pots were then randomly assigned to either the hand watering or drip tube irrigation treatment. Irrigation treatments were not started until one day after inoculation, allowing PMs to become established on the impatiens plants. Three weeks after inoculation with PM, or eleven weeks after seeding, impatiens plants were destructively sampled and the number of PMs on each leaf was counted. Data were analyzed as above.

Effect of irrigation on biological control of TSMs by PMs. This experiment, conducted in Summer 2004, evaluated the impact of irrigation method and frequency on the ability of PMs to control TSM population growth and plant damage from TSM feeding. The factorial treatment structure compared two irrigation methods (overhead or drip tube), two irrigation frequencies (irrigation after either a $20 \%$ or $40 \%$ decline in pot weight from container capacity), and two predator treatments (predators or a no predator control) plus an uninfested control for a total of nine treatments. On plants treated with predators, PMs were released at a 1:10 ratio of predators to prey; this ratio is within the range recommended for control of TSMs on ornamental plants (Hamlen and Lindquist, 1981; Opit et al., 2004). The experimental design was randomized complete block with six blocks (replications).

Irrigation treatments were not started until after predators were applied, as described below. Low irrigation frequency was achieved by weighing eight pots that received this treatment in representative locations at least twice a day. Irrigation was applied when the weight of at least four of the weighed pots dropped by $40 \%$ from their weight at container capacity due to water loss. This resulted in irrigation about 3 times every $4 \mathrm{~d}$. The procedure for irrigating high frequency treatment plants and the six uninfested controls was similar except that eight pots were weighed at least three times a day and plants were irrigated when the container weight 
of at least four of the weighed pots dropped by $20 \%$ from their weight at container capacity. This resulted in irrigating about three times every $2 \mathrm{~d}$. Low and high irrigation frequency plants received approximately equal amounts of fertilizer. This was accomplished by irrigating plants receiving high frequency irrigation with water rather than fertilizer solution about $30 \%$ of the time.

Six weeks after seeding, plants in fifty-three pots were inoculated with 10 adult female TSMs per pot; six additional pots served as uninfested controls. Forty-eight TSM-inoculated plants were randomly assigned among six blocks, eight per block, and the six uninfested control plants were randomly assigned one per block. The five remaining TSM-infested plants were distributed among the benches to allow us to monitor TSM population growth before predator release. Drip tube irrigation of the pots continued as before to allow TSM populations to grow unimpeded. Nine days following TSM inoculation, plants in the five TSM-inoculated pots set aside to monitor TSM growth were destructively sampled to estimate the average number of TSMs per pot. The average number of TSMs on these impatiens was used to calculate the number of predatory mites required to achieve a predator:prey release ratio of $1: 10$. We found an average of $70 \mathrm{TSMs}$ per pot in the five sampled pots, so we released seven PMs per pot, $1 \mathrm{~d}$ after sampling, on those plants scheduled for predator release. Irrigation treatments were not started until one day after inoculation, allowing PMs to become established on the impatiens plants on which they were released. About 3 weeks after predator release, or about 11 weeks after seeding, all leaves on each plant were examined visually for tissue damage related to TSM feeding. For each pot, the number of leaves showing at least $10 \%$ feeding injury on the upper leaf surface were counted. Damage appeared as white or silver to tan stippling marks. All impatiens were then destructively sampled and the number of TSMs on each leaf was counted. The total number of TSMs per pot was determined by addition.

To address the heterogeneity of variance that existed in the data $(\mathrm{z})$, we performed a $\log _{10}(z+1)$ transformation. PROC GLM (SAS, 2000) was then used to run ANOVA to test for the influence of main effects and two- and three-way interactions. To determine how the number of damaged leaves on the uninfested control plants differed from those on plants in other treatments, PROC GLM was used to run ANOVA on transformed data that included the uninfested control treatment. Means were compared using Fisher's least significant difference (LSD) procedure.

\section{Results}

Effect of irrigation method on TSM populations. Irrigation method had a significant effect on TSM populations (Fall 2003: $\mathrm{F}_{1,11}=18.25$, $P=0.0013$; Winter 2004: $\mathrm{F}_{1,11}=42.44, P<$ $0.0001)$. Plants irrigated using overhead watering had much lowernumbers of TSM than plants irrigated using drip tubes (Table 1).

Effect of irrigation method on PM populations. As with TSMs, PM populations were significantly affected by irrigation method (Fall 2003: $\mathrm{F}_{111}=12.78, P=0.0117$; Winter 2004: $\left.\mathrm{F}_{1,11}=16.8, P=0.0018\right)$. Overhead watering resulted in significant reductions in PMnumbers found on plants when compared to drip tube irrigation (Table 2).

Effect of irrigation on the biological control of TSMs by PMs. With respect to numbers of TSMs found on plants, there were no significant two- or three-way interactions among irrigation method, frequency of irrigation, or predator release. Of the main effects, the number of TSMs was only affected by the method of irrigation $\left(\mathrm{F}_{1,35}=37.64, P<0.0001\right)$ and predator release $\left(\mathrm{F}_{1,35}=13.30, P=0.0009\right)$. Plants irrigated using overhead watering had significantly fewer TSMs than plants that were irrigated using drip tubes, and those that received PMs had significantly fewer TSMs than plants that had no PMs (Table 3).

Regarding feeding injury, the only significant two- or three-way interaction was between predator release and irrigation frequency $\left(\mathrm{F}_{135}=\right.$ $5.80, P=0.0215)$. There was no difference between predator release levels when plants were watered more frequently, but when plants were less frequently watered those plants on which predators had been released had significantly less leaf injury (Tables 4 and 5). Irrigation method was the only significant main effect $\left(\mathrm{F}_{1,35}=17.26\right.$, $P=0.0002$ ). Plants irrigated using overhead watering had significantly fewer leaves showing at least 10\% TSM damage than those receiving drip irrigation (Tables 4 and 5).

Table 1. Mean number of twospotted spider mites (TSM) observed on impatiens 'Impulse Orange' irrigated using overhead or drip tube irrigation in Fall 2003 and Winter 2004. Plants were inoculated with TSM 6 weeks after seeding, and TSM were counted 3 weeks later. $\mathrm{N}=12$ for both.

\begin{tabular}{lcc}
\hline & \multicolumn{2}{c}{ Mean no. TSM } \\
\cline { 2 - 3 } Treatment & Fall 2003 & Winter 2004 \\
\hline Drip tube irrigation & $403.8 \mathrm{a}$ & $202.8 \mathrm{a}$ \\
Overhead irrigation & $9.0 \mathrm{~b}$ & $3.0 \mathrm{~b}$ \\
\hline
\end{tabular}

${ }^{2}$ Means within a column followed by different letters are significantly different at $P<0.05$ by Fisher's LSD.

Table 3. Mean number of twospotted spider mites (TSM) observed on impatiens 'Impulse Orange' at different levels of irrigation method (overhead or drip tube), irrigation frequency ( $20 \%$ or $40 \%$ drop in pot weight from container capacity due to water loss), and predator release (no predators or predators). Plants were inoculated with TSM 6 weeks after seeding, predatory mites $(\mathrm{PMs})(P$. persimilis) were released on appropriate treatments 1.5 weeks later, and damage rating and TSM counts were made 3 weeks after that. $\mathrm{N}=24$ for treatments except uninfested control $(\mathrm{N}=6)$.

\begin{tabular}{lr}
\hline Treatment $^{\mathrm{z}}$ & TSM (no.) \\
\hline Irrigation method & \\
Drip tube & $454.7 \mathrm{a}$ \\
Overhead hand watering & $31.4 \mathrm{c}$ \\
Predator release & \\
0 & $373.6 \mathrm{a}$ \\
1 Predator : 10 prey & $112.5 \mathrm{~b}$ \\
Uninfested control & $0.8 \mathrm{~d}$ \\
\hline
\end{tabular}

${ }^{z}$ Main effects and interactions not shown were not significant by ANOVA

${ }^{y}$ Means followed by the same letter are not significantly different at $P<0.05$ by Fisher's LSD.

\section{Discussion}

These results show that overhead watering alone can result in significant reductions in TSM populations and damage due to TSM feeding, even on mite-susceptible plants like impatiens that have a very low aesthetic injury tolerance threshold. This part of our results is consistent with reports of a reduction of TSMs under some type of overhead irrigation (Hudson and Beirne, 1970; Ranga et al., 1990). Conversely, TSMs are more likely to be a serious problem in greenhouses that use irrigation systems that do not wet plant foliage. Currently, irrigation systems that do not wet foliage are widely used in modern, large-scale ornamental greenhouses. Therefore, we recommend that growers who use an automated irrigation system that does not wet foliage (e.g., ebb and flow, trough irrigation, capillary mats, or drip or microtube irrigation) consider their pest management practices in light of a potential increase in TSM populations under these conditions. Specifically, growers using or switching to such systems should consider increasing the thoroughness and frequency of pest monitoring in order to detect TSMs and apply treatments in a timely manner(Opitetal., 2003).

Table 2. Mean number of predatory mites (PMs) ( $P$. persimilis) observed on impatiens 'Impulse Orange' irrigated using overhead or drip tube irrigation in Fall 2003 $(\mathrm{N}=7)$ and Winter 2004( $\mathrm{N}=$ 12). Plants were inoculated with twospotted spider mites 6 weeks after seeding, PMs were released 2 weeks later and were counted 3 weeks later.

\begin{tabular}{lcc}
\hline & \multicolumn{2}{c}{ Mean no. PM $^{\mathrm{z}}$} \\
\cline { 2 - 3 } Treatment & Fall 2003 & Winter 2004 \\
\hline Drip tube irrigation & $181.4 \mathrm{a}$ & $153.8 \mathrm{a}$ \\
Overhead irrigation & $5.6 \mathrm{~b}$ & $0.1 \mathrm{~b}$ \\
\hline
\end{tabular}

${ }^{\mathrm{z}}$ Means within a column followed by different letters are significantly different at $P<0.05$ by Fisher's LSD.

Table 4. Mean number of impatiens 'Impulse Orange' leaves with at least $10 \%$ feeding injury from twospotted spider mite (TSM) at different levels of irrigation method (overhead or drip tube), irrigation frequency $(20 \%$ or $40 \%$ drop in pot weight from container capacity due to water loss), and predator release(no predators or predators). Plants were inoculated with TSM 6 weeks after seeding, predatory mites (PMs) ( $P$. persimilis) were released on appropriate treatments $10 \mathrm{~d}$ later, and damage rating and TSM counts were made 3 weeks later. $\mathrm{N}=24$ for treatments except uninfested control, where $\mathrm{N}=6$.

\begin{tabular}{|c|c|}
\hline Treatment $^{\mathrm{z}}$ & $\begin{array}{c}\text { Injured } \\
\text { leaves } \\
(\text { no. })^{y}\end{array}$ \\
\hline \multicolumn{2}{|l|}{ Irrigation method } \\
\hline Drip tube & $44.6 \mathrm{a}$ \\
\hline Overhead hand watering & $13.5 \mathrm{c}$ \\
\hline \multicolumn{2}{|c|}{ Irrigation frequency $\times$ predator release } \\
\hline \multicolumn{2}{|c|}{$20 \%$} \\
\hline 0 & $29.4 \mathrm{~b}$ \\
\hline 1 Predator: 10 prey & $26.4 \mathrm{~b}$ \\
\hline \multicolumn{2}{|l|}{$40 \%$} \\
\hline 0 & $48.3 \mathrm{a}$ \\
\hline 1 Predator:10 prey & $12.1 \mathrm{c}$ \\
\hline Uninfested control & $0 \mathrm{~d}$ \\
\hline
\end{tabular}

${ }^{\mathrm{z}}$ Main effects and interactions not shown were not significant by ANOVA

${ }^{y}$ Means followed by the same letter are not significantly different at $P<0.05$ by Fisher's LSD. 
Table 5. Mean number of twospotted spider mite (TSM) and mean number of impatiens 'Impulse Orange' leaves showing at least $10 \%$ TSM feeding injury at different levels of irrigation method (overhead or drip tube), irrigation frequency ( $20 \%$ or $40 \%$ drop in pot weight from container capacity due to water loss), and predator release (no predators or predators). Plants were inoculated with TSM 6 weeks after seeding, predatory mites (PMs) (P. persimilis) were released on appropriate treatments $10 \mathrm{~d}$ later, and leaf injury and TSM counts were made 3 weeks later. $\mathrm{N}=24$ for treatments except uninfested control, where $\mathrm{N}=6$.

\begin{tabular}{lcccc}
\hline $\begin{array}{l}\text { Irrigation } \\
\text { method }\end{array}$ & $\begin{array}{c}\text { Treatment } \\
\text { Irrigation } \\
\text { frequency }\end{array}$ & $\begin{array}{c}\text { Predator } \\
\text { release }\end{array}$ & $\begin{array}{c}\text { TSM } \\
(\text { no. })\end{array}$ & $\begin{array}{c}\text { Injured } \\
\text { leaves } \\
(\text { no. })^{2}\end{array}$ \\
\hline Drip tube & 20 & 0 & $492.5 \mathrm{~b}$ & $45.0 \mathrm{~b}$ \\
& & $1: 10$ & $366.8 \mathrm{~b}$ & $40.2 \mathrm{bc}$ \\
& 40 & 0 & $906.2 \mathrm{a}$ & $80.5 \mathrm{a}$ \\
Overhead & 20 & $1: 10$ & $53.3 \mathrm{c}$ & $12.8 \mathrm{c}$ \\
& & 0 & $32.7 \mathrm{~cd}$ & $16.2 \mathrm{c}$ \\
& 40 & 0 & $4.7 \mathrm{~d}$ & $11.3 \mathrm{~cd}$ \\
Uninfested & 20 & $1: 10$ & $63.2 \mathrm{c}$ & $13.8 \mathrm{c}$ \\
& & 0 & $25.2 \mathrm{~cd}$ & $12.7 \mathrm{~cd}$ \\
\hline
\end{tabular}

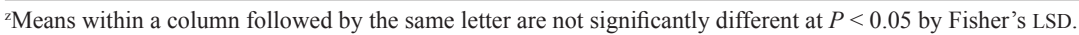

We do not advocate preventative applications of either pesticides or biological control because of high and perhaps unnecessary costs, as well as increased worker safety concerns and pest resistance resulting from overuse of pesticides. If TSMs are detected through regular sampling, effective biological control options are available to use on ornamentals in lieu of pesticides (Gough, 1991; Gould and Light, 1971; Hamlen, 1978; Holt 2005; Opit et al., 2004).

Clearly PMs were negatively affected by overhead watering, and this must be taken into account when choosing remedial or rescue treatment for spider mites. The large reduction in the number of PMs due to overhead irrigation compared to drip tube irrigation may be related to either direct (e.g., physical dislodging, drowning) or indirect (e.g., emigration, death resulting from lack of food, or inhospitable high humidity habitat) adverse effects on the predator, or both. Despite these effects, PMs did reduce TSM populations by approximately the same proportion on plants watered overhead as on plants watered by drip irrigation. However, the substantial reduction in predator populations on impatiens that were watered overhead, combined with evidence that releasing predators on overhead watered plants did not reduce feeding damage more than overhead irrigation alone, indicate that it may not be economical or necessary for growers to invest in biological control for TSMs when overhead irrigations systems are being used. This may not be true for those ornamental greenhouse growers who prefer to grow plants dry (irrigating less frequently) as a means of regulating plant height or toning plants before sale. Under these circumstances, even overhead watering may not sufficiently suppress TSM populations, and PMs are more likely to play an important role in reducing TSMs.

Even when growers irrigate more frequently there are circumstances in which overhead watering might be effectively used in conjunction with biological control of TSMs by PMs. Overhead watering has the potential for quickly knocking down high TSM populations. Therefore, even in greenhouses where overhead irrigation is not used, hand watering could be incorporated into an integrated pest management program for TSMs. For example, hand watering could help reduce TSM populations before releasing predators, particularly in cases where high-density hot spots of TSMs are detected, because PMs are less effective at controlling TSMs at high population levels than at moderate to low TSM densities. This integrated management approach would ensure that PMs are released at TSM densitites that can be rapidly brought under control with predators. In addition, releasing PMs when TSM levels are not extremely high means that fewer predators would have to be purchased, thereby reducing the cost of biological control. Overhead watering may be exploited as an important component of a TSM integrated management program that includes the use of PMs and other management tools.

\section{Literature Cited}

Bauernfeind, R.J. 2004. Insect management for orExt. Publ. MF-2622. 10 Dec. 2005. http://www. oznet.ksu.edu/library/entm12/MF2622.pdf.

Castle, S.J., T.J.Henneberry, and N.C. Tuscano. 1996. Suppression of Bemisia tabaci (Homoptera:Aleyrodidae) infestations in cantaloupe and cotton with sprinkler irrigation. Crop Prot. 15:657-663.

Cranshaw, W.S. and D.C. Sclar. 2004. Spider mites. Colo. State Univ. Coop. Ext. Publ. 5.507. 10 Dec. 2005. http://www.ext.colostate.edu/pubs/ insect/05507.html.

Dole, J.M. and H.F. Wilkins. 2005. Floriculture: Principles and species. 2nd ed. Pearson Education, Inc., Upper Saddle River, N.J.

Gencsoylu, I. and E. Yilmaz. 2003. Influence of various irrigation methods on Frankliniella spp. (Thysanoptera: Thripidae) in cotton fields. Asian J. Plant Sci. 2:768-771.

Gough, N. 1991.Long-term stability in the interaction between Tetranychus urticae and Phytoseiulus persimilis producing successful integrated control on roses in southeast Queensland. Expt. Appl. Acarol. 12:83-101.

Gould, H.J. and W.I. St. G. Light. 1971. Biological control of Tetranychus urticae on stock plants of ornamental ivy. Plant Pathol. 20:18-20.

Hall, K.D., R.L. Holloway, D.T. Smith, J. Anciso, N. Troxclair, and M. Black. 2000. Texas Crop Profile: Onion. Texas Agr. Ext. Serv. Publ. E-18 3-00. 10 Dec. 2005. http://young-co.tamu.edu/publications/OnionProfile.pdf.

Hamlen, R.A. 1978. Biological control of spider mites on greenhouse ornamentals using predaceous mites. Proc. Fla. State Hort. Soc. 91:247-249.

Hamlen, R.A. and R.K. Lindquist. 1981. Comparison of two Phytoseiulus species as predators of twospotted spider mites on greenhouse ornamentals. Environ. Entomol. 10:524-527. ganic vegetable gardeners. Kan. State Univ. Coop.
Holt, K.M. 2005. Developing components of IPM for twospotted spidermite on greenhouse floricultural crops. MS thesis. Kan. State Univ.

Holtzer, T.O., J.M. Norman, T.M. Perring, J.S. Berry, and J.C. Heinz. 1988. Effect of microenvironment on dynamics of spider mite populations. Exp. Appl. Acarol. 4:247-264.

Hudson, W.B and B.P. Beirne. 1970. Effects of sprinkler irrigation on McDaniel and European red mites in apple orchards. J. Entomol. Soc. Brit. Columbia 67:8-13.

Jarvis, W.R. 1992. Managing diseases in greenhouse crops. APS Press, St. Paul, Minn.

Latimer, J.G. and R.D. Oetting. 1999. Conditioning treatments affect insect and mite populations on bedding plants in the greenhouse. HortScience 34:235-238.

Lindquist, R.K., M.L. Casey, and W.L Bauerle. 1987. Effects of an overhead misting system on thrips populations and spider mite-predator interactions on greenhouse cucumber. Bul. IOBC/WPRS 10:97-100.

McHugh, J.J. and R.E. Foster. 1995. Reduction of diamondback moth (Lepidoptera: Plutellidae) infestation in head cabbage by overhead irrigation. J. Econ. Entomol. 88:162-168.

Nakahara, L.M., J.J. McHugh, C.K. Otsuka, G.Y. Funasaki, and P.Y. Lai. 1986. Integrated control of diamondback moth and other insect pests using an overhead sprinkler system, an insecticide, and biological control agents, on a watercress farm in Hawaii. Diamondback moth management, p. 403-413. Proc. 1st Intl. Workshop, Tainan, Taiwan, 11-15 Mar. 1985.

Nelson, P.V. 2003. Greenhouse operation and management. 6th ed. Prentice Hall, Upper Saddle River, N.J.

Opit, G.P., J.R. Nechols, and D.C. Margolies. 2004. Biological control of twospotted spider mites, Tetranychus urticae Koch (Acari: Tetranychidae), using Phytoseiulus persimilis Athias-Henriot (Acari: Phytoseidae) on ivy geranium: assessment of predator release ratios. Biol. Cont. 29:445-452.

Opit, G.P., Y. Chen, K.A. Williams, J.R. Nechols, and D.C. Margolies. 2005. Plant age, fertilization and biological control affect damage caused by twospotted spider mites on ivy geranium: development of action thresholds. J. Amer. Soc. Hort. Sci. 130:159-166.

Opit, G., K. Williams, D. Margolies, J. Nechols, and Y. Chen. 2003. Look before you leap-Managing twospotted spider mites on ivy geranium. Greenhouse Bus. 9 (12):25-26.

Parihar, S.B.S. and S. Name. 1999. Influence of irrigation methods on the aphid, Myzus persicae (Sulzer). Insect Environ. 5: 25-26.

Ranga, G.V.R., D.V.R. Ranga, M.P. Reddy, and J.A. Wightman. 1990. Overhead irrigation and integrated management of spider mites in a groundnut crop. Intl. Arachis Nwslt. 8:23-24.

SAS Institute. 2000. SAS/STAT user's guide. version 8. vol. 3. SAS Inst., Cary, N.C.

Smith, T.J. 2001. Crop profiles for apples in Washington. Wash. State Univ. Coop. Ext. Bul. Publ. MISC0368E 10 Dec. 2005. http://www.tricity. wsu.edu/ cdaniels/profiles/apple.pdf.

Smitley, D. 1993. Two-spotted spider mites, p. 331-336. In: J.W. White (ed.). Geraniums. IV. Ball Publ., Batavia, Ill.

Van de Vrie, M., J.A. McMurtry, and C.B. Huffaker. 1972. Ecology of teranychid mites and theirnatural enemies: A review. III. Biology, ecology and pest status, and host-plant relations of Tetranychids. Higardia 41:343-432.

White, J.C. and O.E. Liburd. 2005. Effects of soil moisture and temperature on reproduction and development of twospotted spider mite (Acari: Tetranychidae) in strawberries. J. Econ. Entomol. 98:154-158. 